UDC 347.2

DOI https:/ / doi.org/10.32841/ILA.2020.23.13

\author{
GUYVAN P. D., \\ Candidate of Legal Sciences, Honored Lawyer of Ukraine, \\ Professor \\ Poltava Business Institute \\ of Academician Yuriy Bugay International Scientific \\ and Technical University
}

\title{
JUSTICE OF JUDICIAL LAW ENFORCEMENT, EUROPEAN POSITIONS AND PRINCIPLES
}

\begin{abstract}
Summary. This work is devoted to the study of a very important in science question about the content and essence of such a phenomenon as a fair trial. The paper examines the procedure for applying the main provisions of the Convention for the Protection of Human Rights and Fundamental Freedoms in Ukrainian law enforcement practice. The main approaches to defining this issue in the case law of the European Court of Human Rights, an international institution designed to ensure uniform application of the Convention, have been studied. The author emphasizes that the quality of justice is a significant external factor that determines the democracy of the state. Ukraine's ability to implement the declared changes to create a system of government that meets European criteria largely depends on reforming the law enforcement system in the direction of justice. It is stated that there are more problems than achievements on this path. Taking into account the European experience, the concept of fairness of a court decision is analyzed as a category that provides the need to assess the applicable law for its legality (requirement for strict observance of law by all parties) and morality (requirement for quality of law), compliance with the need for a court decision. taking into account all the materials of the case (its clarity, consistency, motivation) and the stability of the verdict, which generally guarantees the stability of the legal status of the person as a result of its proclamation. It is emphasized that the requirement of fair trial is aimed at a specific decision as a result of law enforcement activities. In this context, the requirements concern both the content of the court's verdict and the stability and stability of the final court decision designed to be a regulator of public relations.
\end{abstract}

Key words: fair trial, res judicata, quality of law.

Formulation of the problem. The Convention on the Protection of Human Rights and Fundamental Freedoms is the main document that introduces world values into national legal systems and promotes fair and just justice. It is noteworthy that the European Court of Human Rights, which is called upon to apply and interpret convention provisions, is guided in this matter by the principle of legal justice as the main determinant of a proper court. The Convention itself contains a separate normative enshrinement of fair trial indicators in the form of clear and unambiguous provisions. This is according to the rule of Art. 6 in 
the civil law field, a court may be considered fair if it hears the case in public within a reasonable time, being an independent and impartial court established by law, which decides the dispute over the rights and obligations of a civil person. In such circumstances, awareness of the content of the legal certainty of the process and court decisions is achieved through the judicial application of these elements in the decisions of the law enforcement agency.

The European Court of Human Rights has been recognized as an international institution designed to ensure uniform application of the Convention's principles at a practical level, as well as to monitor the fairness of national judgments. This body, developing case law, provides certain clarifications of the definitions and rules of use in the conduct of proceedings of certain provisions of the Convention. In Ukraine, a special law "On the implementation of decisions and application of the case law of the European Court of Human Rights" introduces the status of the Convention and decisions of the ECHR, which gives them the importance of sources of national law and mandatory application of these acts. At the same time, using these documents in their law enforcement practice, the judiciary should use the case law of the Court in the broad sense disclosed in Article 1 of this Law, ie the case law of the ECHR in terms of general human rights, not only decisions on Ukraine.

Review of recent research and publications. The question of the effectiveness and efficiency of the right to a court in the context of its implementation on the basis of legal justice in international and national law is devoted to the study of such scholars as S.P. Holovaty, O.V. Demin, Y.I. Matveeva, M.I. Kozyubra, S.P. Pogrebnyak, M.V. Smutok, O.V. Soloviov, B.C. Stefanyuk, U.Z. Korutz and others. At the same time, having carefully studied the issue of making a fair decision in general, scholars still do not pay enough attention to the analysis of compliance with the requirements of fair trial in the issuance of verdicts by Ukrainian law enforcement agencies in certain civil disputes. In particular, the timeliness of trials, the adherence to the principle of non-overturning of final verdicts and the development of mechanisms for impartial enforcement by national courts have not been adequately clarified. As a result, in the field of Ukrainian judiciary, there is often an arbitrary interpretation of European case law, which does not add legal certainty to public relations. The theoretical solution of these issues is the purpose of this work. This will provide practical recommendations for improving approaches to the fair application of national justice.

Presenting main material. Scientific discussions on the effectiveness of the national judicial system are perhaps the most relevant today in society. As analysts have shown and confirmed by practice, decisions of national courts are often made in violation of European principles of justice. This is convincingly evidenced by a number of ECHR decisions against Ukraine. In 2018 alone, the ECHR received 56350 applications, $12.9 \%$ of which were against Ukraine. During the same 2018, the ECHR issued 86 decisions recognizing our state's violation of the provisions of the European Convention on Human Rights or its protocols [1]. Being a direct source of Ukrainian law, the Convention and the case law of 
the European Court, designed to solve the problems of our judiciary to ensure that the court's verdicts meet the criteria of legal certainty, but now this process is stagnant, with little progress. Therefore, the issue must be resolved immediately, because the authority of the judiciary and the prestige of the state as a whole depend on it. As the quality of the judiciary is a significant external factor that determines the democracy of the state, Ukraine's ability to implement the declared changes to create a system of government that meets European criteria largely depends on reforming the law enforcement system in the direction of justice. The development of ways to solve this problem by developing an appropriate conceptual approach is the purpose of this work.

Judgments of the European Court of Human Rights, on the basis of which the provisions of the 1950 Convention are interpreted and practiced, are a form of case law that extends the normative scope of the Convention by establishing new universally binding rules. The precedent of the Court's position is manifested in the fact that in resolving cases it tends to generally follow the approaches used by it before, if it does not consider it necessary to change them. In particular, in the motivating part of the decision, the court may refer to the arguments expressed in previous decisions instead of reproducing the arguments previously expressed by it. The ECHR has repeatedly emphasized that it is not bound by its own previous decisions and from time to time changes its legal position [2, p. 50]. Thus, the fairness of a court decision should be considered as a factor that ensures the need to analyze and evaluate the applicable law for its legality (requirement for strict compliance with the law by all parties) and morality (requirement for quality of law), compliance with the need for a court decision. taking into account all the materials of the case (its clarity, consistency, motivation) and the stability of the verdict, which generally guarantees the stability of the legal status of the person as a result of its proclamation. The Court emphasizes that the contradictory decisions of the domestic court are themselves a source of legal injustice and violate the law enshrined in Article 6 of the Convention.

The basis of the modern concept of fair justice is the principle of equality of all participants in the process before the court. For every person in a state governed by the rule of law, it is first of all important to have access to justice and the opportunity to freely, quickly, freely exercise the right to judicial protection regardless of belonging to a certain social group or other personal characteristics [3, p. 178]. The European Court of Human Rights quite often refers to this characteristic of a fair trial, postulating that the principles of equality and adversarial proceedings are based on the principle of the rule of law, which is decisive for the entire Convention. At the same time, the legal concepts of "Legality" and "Justice" are not identical, the latter is a category of a higher order and determines not only the legal but also the social effectiveness of justice. However, legality in the process often replaces justice as a phenomenon, as the protection and restoration of rights is possible only within the legal field. Accordingly, equity is introduced into the rank of cost categories when the damage is compared and measured in conventional units of measurement. In this context, the right to a fair trial is a priori, objectively existing and without which it is impossible to restore justice as such [4, p. 25]. 
The requirement of fair trial is aimed at a specific decision as a result of law enforcement activities. In this regard, the requirements concern both the content of the court's verdict (its clarity, consistency, validity, legality and motivation), and the stability and stability of the final court decision, designed to be a regulator of public relations. The ECtHR has repeatedly pointed out that contradictory decisions of national courts may be a separate and additional source of legal uncertainty and, consequently, a violation of the right to a fair trial established by Art. 6 of the Convention for the Protection of Human Rights and Fundamental Freedoms [5, p. 75]. In carrying out their application of the law, courts often have to carry out so-called judicial law-making, which is concerned with the interpretation of national law in accordance with European standards, that is, creative work, in particular with regard to fundamental rights and freedoms. And it is this activity that is largely based on the doctrine of judicial precedent, the content of which is the obligation of the judiciary to comply with their previous decisions (stare decisis). This means the need to adhere to the resolved and not to change the resolved issues [6, p. 316].

The fairness of legal application is based on such principles as legality, specificity and legal expectedness of juridical acts. In this case, legality should be understood as a fundamental legal category that is a criterion of the legal life of society and citizens. This is a "complex political and legal phenomenon that reflects the legal nature of the organization of public life, the organic connection of law and power, law and the state" [7, p. 274]. Judicial verdicts must be clear, understandable and unambiguous. Legal certainty also presupposes respect for the principle of res judicata - the invariability of final (entered into force) court decisions. This means that litigants do not have the right to request a review of a final and binding court decision simply because they aim to obtain a new hearing and a new resolution. The powers of higher judicial review bodies should be exercised to correct judicial errors and shortcomings in the proceedings, but not to conduct a new trial. At the same time, the review should not actually replace an appeal, and the very possibility of the existence of two points of view on one subject is not a basis for a new review. Exceptions to this principle can take place only if there are grounds for important and compelling circumstances.

In the Ukrainian legal system, proper judicial protection of the rights of citizens in civil cases is guaranteed by the constitutional establishment of the principles of justice enshrined in Art. 129 of the Basic Law, such as the equality of all participants in the trial before the law and the court; adversarial nature of the parties and their freedom to present their evidence to the court and to prove their persuasiveness before the court; publicity of the trial and its complete fixation by technical means; reasonable time for consideration of the case by the court; ensuring the right to an appellate review of the case and in cases specified by law to a cassation appeal against a court decision; binding nature of a court decision. Due to their strict observance, the law enforcement body, while administering justice, is independent and governed by the rule of law. In practice, there is often a mixture of legal concepts of "justice" and "legality". Our judges usually deter- 
mine that when a legal relationship is built on the basis of a certain legal act, it should automatically be recognized as legal, and therefore the relevant regulation will be fair. In fact, this is not always the case, and with such a construction lies a significant methodological error. Crucial in the sense of guaranteeing the certainty of the rule of law should be given not to its literal content, but to the qualitative characteristics of legal requirements. After all, the content of the law can be distorted in the process of creating and applying the act. Therefore, the thesis of denying the idea of identifying law and law is important. Because only the lawful in positive law is lawful and lawful. Law is a specific form of expression of law [8, p. 135]. Therefore, the laws that regulate the mechanisms of organization and functioning of state bodies, establish the legal tools that mediate material legal relations, must be harmoniously combined with other laws. This approach will ensure the introduction of fundamental values in the state, such as humanism, democracy, freedom, justice, etc. It is in this sense that the concept of "legal law" has the right to exist $[9$, p. 90$]$.

In establishing the criteria of fairness of the rule of law, it should be borne in mind that the rule of law as the highest principle of building the law state is characterized by at least three constituent principles belonging to the so-called procedural natural law: "law - going in future"; "The law is clear"; "The law is general". They contain the content that provides a set of substantive rules that have an internal nature in relation to the law [10, p. 759]. These principles necessarily provide for the possibility of proper expectation and clarification of the content of the legal consequences for the effective exercise of a person's rights. In this case, the temporal dimension, in addition to the direction of the law for the future, indicates the need for its application only after public disclosure, and also requires the legislator predictability of legislative policy in the social sphere, which means the inadmissibility of unexpected changes in legislation. stability of legal norms, which should be understood as the lack of frequent changes in regulations, because otherwise public relations will not have time to adapt to new regulatory conditions [6, p. 322-323]. Therefore, the principle of justice of the law is usually considered as a set of requirements for the organization and functioning of the legal system in order to ensure a stable legal position of the individual by improving the processes of lawmaking and law enforcement.

This is how the European Court of Human Rights postulates the concept of "law". He points out that it should be understood as both the rules established by written law and the rules formed in case law. The law must meet the quality requirements, first of all, the requirements of "accessibility" and "predictability". This means that the "law" must be properly accessible: the citizen must be able to obtain adequate information in the circumstances of the application of legal norms in a particular case. In addition, a norm cannot be considered a "law" if it is not formulated with sufficient clarity so that a citizen can regulate his behavior. The citizen should be able - if necessary with appropriate legal assistance - to predict, as far as it is reasonable in specific circumstances, the consequences that may lead to a particular action [11, p. 37]. 
The scientific literature has repeatedly stated that it would be fair to consider a case in a court based on the principles of equality of arms, equal access to justice; competitiveness; publicity of justice; independence and impartiality of the court; effective participation of the parties in the case; observance of the right to protection; reasonable time for consideration of the case [12, p. 51]. Given the multifaceted nature of these criteria, the issues of fairness of the trial and the correctness or erroneousness of the judgment should not be confused and substituted. One of the main principles of a fair and honest process is the independence and impartiality of the judiciary. The independence of the court is a very important feature of a jurisdictional body, which largely determines the effectiveness of this body in the perception of ordinary citizens. This is especially significant in the context of our national judiciary, which, according to numerous opinion polls, is prone to illegal influence from the government, business and other non-legal entities. Therefore, the impartiality of the court should mean its activity exclusively on the basis of the current legislation, taking into account the principle of the rule of law, on the basis of professional knowledge and own legal awareness, excluding any outside influence and control. In other words, the independence of a judge means the absence of any interest in the administration of justice, objectivity and complete impartiality towards the participants in the proceedings.

It is very important that the judge has a sense of honesty and justice. However, in practice, it is difficult to assess these criteria. Therefore, transparent procedures and consistency of practice should be applied. The internal independence of the judiciary requires that judges be free from instructions or pressure from other judges or persons performing administrative duties in the court, such as the chairman of the court or the chairman of the panel. The lack of sufficient guarantees to ensure the independence of judges within the judiciary, and in particular from the judiciary, may lead the ECtHR to conclude that the applicant's doubts about the independence and impartiality of the court are objectively justified [13, para. 86]. According to the Court's settled case-law, the existence of impartiality for the purposes of Article $6 \$ 1$ of the Convention must be determined on the basis of a subjective criterion which takes into account the personal convictions and conduct of a judge, which means determining whether a judge personal interest or bias, as well as on the basis of an objective criterion, in the context of which it is necessary to establish whether the court and, among other aspects, its composition, sufficient guarantees to exclude any reasonable doubts about its impartiality [14, para. 27, 28 and 30]. Thus, it must be decided in each individual case whether the relationship in question is of such a nature and degree as to indicate the impartiality of the court.

Judges' independence implies not only their alienation from other branches of government, but also their lack of decisive influence within the judiciary, and the need to avoid the risk of a judge being pressured by their colleagues to initiate disciplinary proceedings and make other career decisions. In particular, such a situation was the subject of consideration in the decision of the European Court of Human Rights "Gazeta Ukraina Tsentr v. Ukraine” [15, p. 32-34]. The appli- 
cant company complained that the courts of first and appellate instance were not independent and impartial because the plaintiff in the case was the chairman of the Kirovohrad Regional Council of Judges and could influence any of the judges in the region. The applicant provided information stating, inter alia, that forms of pressure on judges by the council included threats to "complicate professional careers" and "initiate dismissal or disciplinary action". According to these documents, judges' councils could influence a judge's professional career. In turn, the Government denied that the judiciary in Ukraine enjoyed institutional and financial independence. The Government noted that in the impugned proceedings the plaintiff, as the head of a collegial body - the Council of Courts - had no influence on the decisions of the courts of first and appellate instance.

In considering the merits of the case, the Court noted that, in the context of an objective criterion in the present case, apart from the conduct of the judges, it should be determined whether there were convincing facts which might cast doubt on their impartiality. This means that in deciding whether there are reasonable grounds to fear in a case that a particular judge was impartial, the position of the person concerned is important but not decisive. The decisive factor is whether such fears can be considered objectively justified. In view of this, even external manifestations can be important or, in other words, "justice must not only be done, it must also be seen that it is done". At stake is the trust that courts must instill in a democratic society. From this point of view, the validity of the doubts as to whether judges may be influenced by their colleagues is relevant. Thus, the applicant company could reasonably have foreseen a possible conflict of interest in the said proceedings. Thus, in the Court's view, the applicant company's concerns about the impartiality of the judges of the courts of first and appellate instance may be considered objectively justified. In the present case there has been a violation of Article $6 ₫ 1$ of the Convention.

As we can see, there is a big problem with the independence of the judiciary in Ukraine. In resolving the question of the fairness of the judicial process, an essential reference point for the national legal system is the international practice that has developed and established the procedure for regulating these relations. This is all the more important because according to our legislation, the Convention and decisions of the European Court of Human Rights are sources of Ukrainian law. But the problem in Ukraine is that the unity of criteria for using the case law of the European Court in considering specific court cases has not been developed. Mostly in real proceedings, if a reference is made to a decision of the ECtHR, it is abstract in nature. Quite often, such a reference to international case law has nothing to do with the facts of the case. However, if the decision of the Court used to substantiate the position of the national law enforcement authority is related to certain circumstances of the case, the court does not provide reasons for its compliance with Ukrainian law. In fact, the justification of the position of a party or court in the process is not only the mention of such a decision in the court verdict, but also a detailed analysis of its applicability to a particular case. This must be clearly and reasonably motivated by the court. Only 
under these conditions is the use of a judgment of the European Court of Human Rights justified. If the relevant motivation confirms the legal side of the proceedings, this must be stated in the decision, and this argument is very important for the established concept of a fair trial. However, where the decision of the ECtHR is not relevant to the subject matter of the dispute, the court must reject a certain reference as formal and inconsistent with due justification.

We must draw certain conclusions from the study. One of the important tasks of the European Court of Human Rights is to help democratize the legislation and law enforcement of countries seeking to join the EU. Therefore, the introduction of a reliable mechanism for the protection of human rights in court proceedings is a necessary condition for reforming the legislation of Ukraine. The ECtHR draws attention to this aspect, as the lack of such legal guarantees poses a "great danger" to the rule of law, when serious violations of the administration of justice occur within national legal systems, for which the parties do not have any national remedies. protection of the violated right. The importance of ensuring a fair trial led to the development of the ECtHR's position on the need for special legal instruments in national law by which the applicant could challenge abuses in the proceedings. Unfortunately, we must state that the relevant legal mechanism does not currently exist in Ukraine, especially in the case of violation of the right to a fair trial by the Supreme Court. Therefore, the number of appeals to the ECtHR will only increase over time.

\section{References:}

1. Ющенко Т.В. Практика ЄСПЛ: переосмислити не можна застосувати. Право : вебсайт. URL: https://pravo.ua/praktika-iespl-pereosmisliti-ne-mozhnazastosovuvati.

2. Коруц У.3. Міжнародно-правовий захист права на справедливий судовий розгляд в практиці Європейського суду з прав людини та правозастосовна практика України : дис. ... канд.. юрид. наук : 12.00.11. Київ, 2015. 229 с.

3. Городовенко В.В. Принцип рівності громадян перед законом і судом. Вісник Конституційного Суду України. 2012. № 1. С. 178-186.

4. Коруц У.3. Міжнародно-правовий захист права на справедливий судовий розгляд в практиці Європейського суду з прав людини та правозастосовна практика України : дис. ... канд.. юрид. наук : 12.00.11. Київ, 2015. 229 с.

5. Рукавишникова А.А. Генезис категории «правовая определенность» в современной юридической науке. Вестник Томского государственного университета. Серия «Право». 2014. № 3 (13). С. 71-81.

6. Шевчук С.В. Судова правотворчість: світовий досвід і перспективи в Україні. Київ : Реферат, 2007. 640 с.

7. Бобровник С.В. Законність. Великий енциклопедичний юридичний словник / за ред. акад. НАН України Ю.С. Шемшученка. Київ : Юридична думка, 2007. 992 c.

8. Кормич A.I. Історія вчень про державу і право : навчальний посібник. 3-тє вид., перероб. та доп. Київ : Алерта, 2012. 334 с.

9. Fuller L. The Morality of Law. Yale University Press, 1969. 262 p.

10. Головатий С.П. Верховенство права. Книга друга. Від доктрини - до принципу. Київ : Видавництво «Фенікс», 2006. С. 625-1276. 
11. Judgment of the European Court of Human Rights of 23 June 1995 in Tolstoy Miloslavsky v. The United Kingdom, application № 18139/91. URL: https://hudoc.echr.coe.int/eng\#\{"itemid":["001-57947"]\}.

12. Reid Karen. A Practitioner's Guide to the European Convention on Human Rights. 2nd ed. London : Thompson / Sweet \& Maxwell, 2004. 648 p.

13. Judgment of the European Court of Human Rights of 22 December 2009 in ParlovTkalcic v. Croatia, application № 24810/06. URL: http://www.alppp.ru/court/ vysshie-sudy/12-2009/informacija-o-postanovlenii-espch-ot-22-12-2009-po-deluparlov-tkalchich---protiv-horvatii.pdf.

14. Judgment of the ECtHR of 24 February 1993 in Feyv. Austria, application № 14396/88. URL: https://hudoc.echr.coe.int/eng\#\{"itemid":["001-57808"]\}.

15. Judgment of the European Court of Human Rights of 15 July 2010 in Gazeta Ukraina-Tsentr v. Ukraine, application № 16695/04. URL: https://cedem.org.ua/ library / sprava-gazeta-ukrayina-tsentr-proty-ukrayiny /.

Гуйван П. Д. Справедливість судового правозастосування, європейські засади та принципи

Анотація. Праця присвячена дослідженню вельми значущого в науці питання про зміст і сутність такого явища, як справедливий суд. У роботі досліджено порядок застосування в українській правозастосовній практиці основних положень Конвенції про захист прав людини й основоположних свобод. Вивчено головні підходи в наданні визначення цьому питанню в прецедентних рішеннях Європейського суду з прав людини, міжнародної інституції, яка покликана забезпечити одноманітність застосування конвенційних засад. Автор підкреслює, що якість судочинства $є$ значним зовнішнім чинником, який визначає демократичність держави. Від реформування правозастосовної системи в напрямі справедливості значною мірою залежить здатність України здійснити задекларовані нею зміни щодо створення системи влади, що відповідає європейським критеріям. Констатовано, що на такому шляху більше проблем, ніж здобутків. 3 урахуванням європейського досвіду проаналізовано поняття справедливості судового рішення як категорії, що забезпечує необхідність оцінювати застосовувану правову норму на предмет ії законності (вимога щодо режиму суворого дотримання норм права всіма учасниками відносин) і моральності (вимога щодо якості закону), дотримання необхідності винесення судового рішення з урахуванням усіх матеріалів справи (його ясності, несуперечливості, вмотивованості) й стійкості вердикту, що загалом гарантує стабільність правового статусу особи внаслідок його проголошення. Наголошується, що вимога справедливості судового розгляду спрямована до конкретного рішення як результату правозастосовної діяльності. У такому контексті вимоги стосуються як змісту самого вердикту суду, так і стійкості й стабільності остаточного судового рішення, покликаного бути регулятором суспільних відносин.

Ключові слова: справедливий суд, res judicata, якість закону. 